\title{
Metode Shared Reading dan Kemampuan Membaca Pemahaman (Studi di SDN Garatengah Kecamatan Japara Kabupaten Kuningan
}

\author{
Agus Saeful Anwar \\ Pendidikan Guru Sekolah Dasar, STKIP Muhammadiyah Kuningan \\ Email: saefulanwar@upmk.ac.id
}

\begin{abstract}
ABSTRAK: Penelitian ini bertujuan untuk mengetahui pengaruh penggunaan metode berbagi membaca terhadap kemampuan membaca. Penelitian ini dilatarbelakangi oleh rendahnya kemampuan pemahaman membaca materi pokok cerita rakyat dalam pembelajaran bahasa Indonesia, yakni: di bawah nilai KKM yaitu 75. Penelitian ini merupakan penelitian eksperimental. Subjek penelitian kelas V SD Garatengah. Populasi dalam penelitian ini adalah seluruh siswa kelas V SDN Garatengah Kecamatan Japara Kabupaten Kuningan yang berjumlah 24 siswa. Teknik pengambilan sampel dalam penelitian ini adalah total sampling, penulis mengambil seluruh populasi untuk dijadikan sampel untuk siswa kelas V SDN Garatengah yang berjumlah 24 siswa saja. Teknik pengumpulan data yang digunakan dalam penelitian ini adalah tes pilihan ganda dan dokumentasi. Teknik analisis data yang digunakan dalam penelitian ini adalah uji normalitas, uji homogenitas, dan uji hipotesis (wilcoxon-test). Berdasarkan perhitungan statistik diperoleh nilai signifikansi 0,000<0,05 maka Ha diterima artinya ada pengaruh pemahaman membaca siswa dengan menggunakan metode shared reading pada materi pokok cerita rakyat di kelas V SDN Garatengah.
\end{abstract}

Kata kunci: Metode Share Reading, Pemahaman Membaca

\begin{abstract}
This study aims to determine the effect of using the reading sharing method on reading ability. This research is motivated by the low reading comprehension ability of the subject matter of folklore in Indonesian language learning, namely: below the KKM value of 75. This research is an experimental study. The research subject was grade V SD Garatengah. The population in this study were all fifth grade students of SDN Garatengah, Japara District, Kuningan Regency, totaling 24 students. The sampling technique in this study was total sampling, the authors took the entire population to be the sample for grade V SDN Garatengah students, totaling 24 students only. The data collection techniques used in this study were multiple choice tests and documentation. The data analysis techniques used in this study were normality test, homogeneity test, and hypothesis test (Wilcoxon-test). Based on statistical calculations, the significance value is $0.000<0.05$, so Ha is accepted, meaning that there is an effect of students' reading comprehension using the shared reading method on the subject matter of folklore in grade V SDN Garatengah
\end{abstract}

Keywords: Method Shared Reading, Reading Understanding 


\section{PENDAHULUAN}

Pembelajaran Bahasa Indonesia memiliki peranan yang sangat penting. Bukan hanya untuk membina keterampilan komunikasi juga untuk kepentingan penguasaan ilmu pengetahuan. Melalui bahasalah manusia belajar berbagai macam pengetahuan yang ada di dunia. Oleh karenanya wajar jika banyak orang menganggap bahasa sebagai induk pengetahuan. Pembelajaran Bahasa Indonesia diberikan pada seluruh jenjang pendidikan dari tingkat sekolah dasar hingga perguruan tinggi. Keterampilan utama Bahasa Indonesia yaitu (menyimak, berbicara, membaca dan menulis) dan dua aspek keterampilan penunjang yakni Kebahasaan dan Apresiasi Bahasa dan Sastra Indonesia, yang dalam pelaksanaannya aspek-aspek itu dijadikan fokus dalam setiap pertemuan (Santosa, 2009).

Salah satu pembelajaran dalam Bahasa Indonesia yaitu pembelajaran membaca dimana pada hakikatnya pembelajaran membaca sangat penting bagi siswa karena kemampuan membaca berkaitan dengan proses memahami dan memberi makna, memanfaatkan dengan tepat bahan bacaan yang dibaca untuk meningkatkan pengetahuan dan wawasan sehingga memiliki kemampuan lebih dari orang lain. Pembelajaran membaca dapat diartikan sebagai serangkaian aktivitas yang dilakukan siswa untuk mencapai keterampilan membaca. Pembelajaran membaca bukan semata-mata dilakukan agar siswa mampu membaca, melainkan sebuah proses yang melibatkan seluruh aktivitas mental dan memproduksi sebuah wacana tertulis.

$$
\text { Tarigan (2008: 7), }
$$
mengungkapkan membaca adalah suatu proses yang dilakukan untuk memperoleh pesan yang hendak disampaikan oleh penulis melalui media kata-kata/bahasa tulis. Perintah tentang membaca tertulis dalam surat Al-Alaq adalah surat yang pertama kali diturunkan pada Rasul shallallahu'alaihi wa sallam. Surat tersebut adalah surat Makkiyah. Diawalawal surat berisi perintah membaca. Yang dengan membaca dapat diketahui perintah dan larangan Allah. Jadi manusia bukanlah dicipta begitu saja di dunia, namun juga diperintah dan dilarang. Allah Ta'ala berfirman:

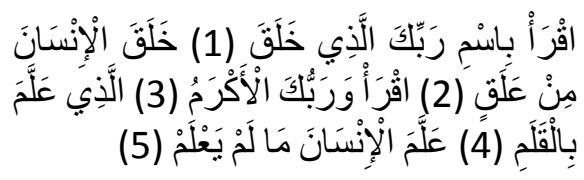

Artinya: Bacalah dengan (menyebut) nama Rabbmu Yang menciptakan, Dia telah menciptakan manusia dari segumpal darah. Bacalah, dan Rabbmulah Yang Maha Pemurah. Yang mengajar (manusia) dengan perantaran qolam (pena). Dia mengajar kepada manusia apa yang tidak diketahuinya (QS. Al 'Alaq [96]: 1-5).

Tujuan akhir dari membaca adalah memahami isi bacaan, tetapi kenyataan yang ada belum semua siswa dapat mencapai tujuan tersebut. Banyak siswa yang dapat membaca lancar suatu bahan bacaan tetapi tidak memahami isi bahan bacaan tersebut. Membaca pemahaman merupakan salah satu aspek kemampuan berbahasa yang harus dikuasai oleh siswa sekolah dasar terutama pada kelas lanjut. Membaca pemahaman merupakan istilah yang digunakan untuk kegiatan membaca yang bertujuan untuk memperoleh informasi yang terkandung dalam teks bacaan. Menurut Tarigan (2008: 58), membaca pemahaman (reading for undersanding) adalah jenis membaca untuk memahami standarstandar atau norma kesastraan, resensi kritis, drama tulis, dan pola-pola fiksi 
dalam usaha memperoleh pemahaman terhadap teks, pembaca menggunakan strategi tertentu. Pemilihan strategi berkaitan erat dengan faktor-faktor yang terlibat dalam pemahaman, yaitu pembaca dan konteks.

Berdasarkan observasi awal dilapangan pada tanggal 15 September 2019 yaitu pada saat proses pembelajaran Bahasa Indonesia, diketahui bahwa kemampuan membaca pemahaman siswa kelas $V$ SD Negeri Garatengah Tahun Pelajaran 2019/2020 masih rendah. Hal ini dapat dilihat ketika proses pembelajaran berlangsung pada materi membaca pemahaman, ketika guru mengajukan pertanyaan mengenai isi bahan bacaan yang dibaca, hanya 3 siswa saja yang mampu menjawab pertanyaan guru dari 24 siswa. Selebihnya masih banyak siswa yang cenderung diam dan tidak bisa menjawab.

Faktor yang mempengaruhi kemampuan membaca pemahaman yang rendah diantaranya penyampaian guru yang kurang menarik, penggunaan media atau metode yang kurang tepat sehingga kemampuan membaca pemahaman siswa kurang memenuhi nilai KKM. Berdasarkan hasil pengamatan dan dokumentasi yang peneliti lakukan dengan guru kelas $\mathrm{V}$ terdapat 4 siswa atau sekitar 1,38\% dari jumlah 24 siswa yang sudah memenuhi nilai KKM dan selebihnya masih kurang dari nilai KKM yaitu 75 .

Dari hasil pengamatan permasalahan yang muncul yaitu guru dalam menerangkan materi hanya menggunakan metode ceramah sehingga siswa tidak sepenuhnya paham terhadap materi yang disampaikan guru dan merasa bosan pada saat proses pembelajaran berlangsung, sehingga menimbulkan kurangnya minat baca dan dalam perhatian siswa terhadap materi yang disampaikan guru. Pada saat proses pembelajaran berlangsung, tidak semua siswa mengikuti prosedur pembelajaran yang dirancang guru, akan tetapi ada sebagian siswa yang diam dan belum menunjukkan keterlibatan siswa secara aktif dalam proses pembelajaran, sehingga aktivitas belajar siswa masih rendah.

Berdasarkan permasalahan di atas bahwa kemampuan membaca masih jauh dari yang diharapkan. Seorang guru sebagai fasilitator hendaknya memperhatikan prinsip dan tujuan yang ada dalam pembelajaran bahasa Indonesia khususnya kemampuan membaca sehingga proses pembelajaran membaca akan berjalan dengan baik sesuai dengan yang diharapkan. Peran siswa secara aktif dalam kegiatan belajar mengajar sangat diperlukan agar belajar menjadi efektif dan dapat mencapai hasil yang diinginkan.

Dari permasalahan pembelajaran yang terjadi seperti di atas, dapat diatasi dengan menerapkan metode shared reading. Dengan penerapan metode pembelajaran ini dapat dijadikan sebagai alternatif untuk meningkatkan kemampuan membaca pemahaman siswa. Melalui metode ini pembelajaran membaca diharapkan dapat lebih menyenangkan dan jauh dari rasa membosankan.

\section{Membaca Pemahaman}

Shared reading merupakan metode pembelajaran membaca yang bertujuan agar siswa dapat memahami sebuah wacana utuh berlandaskan kerja sama atau saling berbagi informasi. Shared reading pada prinsipnya adalah kegiatan membaca berbasis pembelajaran kooperatif sehingga setiap siswa memiliki peran yang sangat penting bagi terwujudnya pemahaman wacana secara utuh bagi temannya (Abidin, 2012: 88 ). Metode shared reading merupakan kegiatan membaca bersama antara guru dengan siswa. Setiap siswa diharapkan 
memiliki bahan bacaannya untuk dibaca bersama (dalam jurnal Purnamasari, 2015:18).

Shared reading merupakan metode pembelajaran membaca yang bertujuan agar siswa dapat memahami sebuah wacana utuh berlandaskan kerja sama atau saling berbagi informasi. Shared reading pada prinsipnya adalah kegiatan membaca berbasis pembelajaran kooperatif sehingga setiap siswa memiliki peran yang sangat penting bagi terwujudnya pemahaman wacana secara utuh bagi temannya (Abidin, 2012: 88).

Metode shared reading dibentuk dengan berbasiskan pembelajaran kooperatif. Dalam konteks ini antara siswa memiliki hubungan ketergantungan positif. Tidak akan lengkap pemahaman isi wacana jika ada seorang yang tidak terlibat aktif dalam memahami bacaan pada bagian yang menjadi tanggung jawabnya. Dengan demikian pemahaman menyeluruh isi bacaan akan bergantung pada peran serta secara aktif seluruh siswa.

Menurut Tarigan (2008:

58), membaca pemahaman (reading forunder standing) adalah sejenis membaca yang bertujuan untuk memahami standar-standar atau normanorma kesastraan (literal standar), resensi kritis (critical review), drama tulis (priented drama) serta pola-pola fiksi (patternof ficion). Sedangkan menurut Somadayo (2011:10), membaca pemahaman merupakan suatu proses pemerolehan makna yang secara aktif melibatkan pengetahuan dan pengalaman yang telah dimiliki oleh pembaca serta dihubungkan dengan isi bacaan.

\section{METODE PENELITIAN}

Penelitian ini merupakan penelitian eksperimental. Subjek penelitian kelas V SD Garatengah. Populasi dalam penelitian ini adalah seluruh siswa kelas V SDN Garatengah Kecamatan Japara Kabupaten Kuningan yang berjumlah 24 siswa. Teknik pengambilan sampel dalam penelitian ini adalah total sampling, penulis mengambil seluruh populasi untuk dijadikan sampel untuk siswa kelas V SDN Garatengah yang berjumlah 24 siswa saja. Teknik pengumpulan data yang digunakan dalam penelitian ini adalah tes pilihan ganda dan dokumentasi. Teknik analisis data yang digunakan dalam penelitian ini adalah uji normalitas, uji homogenitas, dan uji hipotesis (wilcoxon-test) digunakan untuk mengetahui pengaruh peningkatan kemampuan pemahaman membaca siswa dengan menggunakan metode pembelajaran bahasa Indonesia pada materi pokok cerita rakyat. di kelas $\mathrm{V}$ Negara Bagian Garatengah.

\section{HASIL PENELITIAN DAN PEMBAHASAN}

Berdasarkan hasil pengolahan dan analisis terhadap data hasil penelitian dan hipotesis yang peneliti sajikan, maka hasil penelitian tersebut dapat peneliti bahas yaitu terdapat pengaruh metode shared reading terhadap kemampuan membaca pemahaman siswa. Berikut pembahasan hasilnya sebagai berikut:

\section{Kemampuan Membaca Pemahaman Siswa pada Materi Pokok Cerita Rakyat Sebelum Menggunakan Metode Shared Reading}

Berdasarkan hasil analisis data pretest hasil kemampuan membaca pemahaman materi pokok cerita rakyat kelas V SD Negeri Garatengah Kecamatan Japara Kabupaten Kuningan sebelum mengunakan metode shared reading memperoleh nilai terendah sebesar 50 , nilai terbesar sebesar 65 dan memperoleh rata-rata sebesar 58,37 , hal ini membuktikan bahwa kemampuan membaca pemahaman siswa di SD Negeri Garatengah sebelum menggunakan metode shared reading masih rendah. 
Rendahnya kemampuan

membaca pemahaman siswa dikarenakan pembelajaran yang dilakukan masih sederhana, guru hanya menggunakan metode ceramah, diskusi dan penugasan. Guru menyampaikan pembelajaran Bahasa Indonesia secara verbal, hal tersebut menjadikan kurangnya partisifasi aktif siswa dalam pembelajaran. Kelemahan metode ceramah adalah siswa akan cepat bosan dan menyebabkan siswa menjadi pasif. Dengan demikian pembelajaran yang dilakukan menyebabkan rendahnya kemampuan membaca pemahaman siswa.

\section{Kemampuan Membaca Pemahaman Siswa pada Materi Pokok Cerita Rakyat Setelah Menggunakan Metode Shared Reading}

Berdasarkan hasil analisis data posttest kemampuan membaca pemahaman materi pokok cerita rakyat di kelas V SD Negeri Garatengah Kecamatan Japara Kabupaten Kuningan setelah menggunakan metode pembelajaran shared reading memperoleh nilai terendah sebesar 75, nilai terbesar sebesar 90 dan memperoleh rata-rata sebesar 80,20, hal ini membuktikan bahwa penggunaan metode shared reading dapat meningkatkan kemampuan membaca pemahaman siswa pada materi pokok cerita rakyat di kelas V SD Negeri Garatengah Kecamatan Japara Kabupaten Kuningan.

\section{Pengaruh Penggunaan Metode Shared Reading terhadap Kemampuan Membaca Pemahaman Siswa pada Materi Pokok Cerita Rakyat}

Berdasarkan perhitungan uji normalitas data pretest diperoleh nilai signifikasi sebesar 0,005 0,05 maka data tidak berdistribusi normal, sedangkan uji normalitas data posttest diperoleh nilai signifikasi sebesar 0,001 < 0,05 maka dapat disimpulkan data tidak berdistribusi normal.

Dari hasil perhitungan uji homogenitas diperoleh nilai signifikasi sebesar 0,117>0,05 maka dapat disimpulkan data pretest dan posttes mempunyai variansi yang homogen. Karena data tidak berdistribusi normal dan homogen maka pengujian hipotesis menggunakan uji hipotesis wilcoxon.

Perhitungan uji hipotesis wilcoxon secara statistik diperoleh nilai signifikasi $0,000<0,05$ maka $H_{a}$ diterima dan menolak $\mathrm{H}_{0}$, artinya terdapat pengaruh terhadap kemampuan membaca pemahaman siswa dengan menggunakan metode pembelajaran shared reading pada materi pokok cerita rakyat di kelas $\mathrm{V}$ SD Negeri Garatengah.

Berdasarkan pembahasan tersebut terbukti bahwa penggunaan pembelajaran metode shared reading terdapat pengaruhnya terhadap kemampuan membaca pemahaman siswa dalam pembelajaran Bahasa Indonesia pada materi pokok cerita rakyat di kelas V SD Negeri Garatengah.

\section{SIMPULAN}

Berdasarkan hasil pengolahan data dan pembahasan tentang pengaruh penggunaan metode shared reading terhadap kemampuan membaca pemahaman siswa pada materi pokok cerita rakyat di kelas $V$ SD Negeri Garatengah Kecamatan Japara Kabupaten Kuningan, maka peneliti menarik kesimpulan sebagai berikut:

1. Kemampuan membaca pemahaman pada materi pokok cerita rakyat sebelum menggunakan metode shared reading masih rendah, dengan memperoleh nilai rata-rata sebesar 58,37, berada di bawah kriteria ketuntasan minimal yang telah ditetapkan yaitu sebesar 75 .

2. Kemampuan membaca pemahaman pada materi pokok cerita rakyat 
setelah menggunakan metode shared reading sangat tinggi dengan nilai rata-rata sebesar 80,20 , berada di atas kriteria ketuntasan minimal yang telah ditetapkan yaitu sebesar 75.

3. Terdapat pengaruh kemampuan membaca pemahaman dengan menggunakan metode shared reading pada materi pokok cerita rakyat di kelas $V$ SD Negeri Garatengah, dengan nilai signifikasi 0,000 . Maka $\mathrm{H}_{\mathrm{a}}$ diterima dan menolak $\mathrm{H}_{0}$, artinya terdapat pengaruh terhadap kemampuan membaca pemahaman siswa dengan menggunakan metode shared reading pada materi pokok cerita rakyat di kelas $V$ SD Negeri Garatengah Tahun 2019.

\section{UCAPAN TERIMAKASIH}

Tulisan ini tersusun atas dukungan pimpinan STKIP Muhammadiyah Kuningan, dan semangat dari temanteman dosen di Prodi Pendidikan Guru Sekolah Dasar. Oleh karena itu, kami mengucapkan terimakasih kepada semua pihak yang telah ikut berkontribusi. Ucapan terima kasih juga penulis berikan kepada kepala editor Journal of Education and Teaching (JET), Ibu Tri Indah Rusli, dan TIM yang menyediakan media, dan telah memberikan saran, masukan, demi kesempurnaan artikel ini

\section{DAFTAR PUSTAKA}

Abidin, Yunus. (2012). Pembelajaran Membaca Berbasis Pendidikan Karakter. Bandung: PT Refika Aditama.

Purnamasari, Dewi. (2015). Perbandingan Efektivitas Metode Turnamen Membaca dan Metode Shared Reading Terhadap Peningkatan Kemampuan Membaca

Pemahaman Fiksi Anak. Antologi UPI. Tahun 2015, hal 1-8.
Santosa, Puji. (2009). Materi Pembelajaran Bahasa Indonesia. Universitas Terbuka.

Somadayo, Samsu. (2011). Strategi dan Teknik Pembelajaran Membaca. Yogyakarta: Grahallmu.

Tarigan, Henry Guntur. (2008). Membaca Sebagai Suatu Keterampilan Berbahasa. Bandung: Angkasa Bandung. 